\title{
A Lean Approach To Manage A Capstone Senior Project Course
}

\author{
Manocher Djassemi \\ Industrial Technology Area Orfalea College of Business \\ California Polytechnic State University \\ San Luis Obispo, CA 93407 djassemi@calpoly.edu
}

\begin{abstract}
The senior project course (IT461) in the Industrial Technology program at California Polytechnic State University (Cal Poly) is a quarter long capstone course that complements the "learn-by-doing" educational approach at Cal Poly. Our short time frame, an 11-week academic quarter, poses a challenge for both students and faculty. This paper provides details of a new design for the IT461 course. A lean, paperless approach to course management is presented. Using this approach, little or no paper is exchanged between students and faculty. The reduction in waste can be significant in engineering or technology senior project courses. Evaluation of the results shows that students see paperless course management as an effective approach to improving the value of the course in short time available. Examples of industry-based projects that were completed under the modified program are presented.
\end{abstract}

Index Terms - Capstone, senior projects, value stream mapping, paperless course design.

\section{INTRODUCTION}

The industrial technology (IT) program at Cal Poly is due in large part to the demand of the local and regional industrial community for a technically educated workforce. The graduates of this program can make an immediate and relevant contribution to industry. The Senior Project course (IT461) has an important role in complementing the "learn-by-doing" education of industrial technology students at Cal Poly. The projects are intended to solve technology-oriented or industrial management problems in businesses or industrial firms. The Senior Project is a required course in all programs at Cal Poly including the IT program where the objectives of the course include:

- applying a subset of skills and techniques that students have learned during their undergraduate studies to realworld problems,

- developing solutions for improving the management of materials, labor, and machines, and

- enhancing the technical writing ability of students

through development of a professional report that details their project activities.
Project deliverables typically involve the following items:

- a physical product prototype, a plan for improving a management system or procedure,

- intermediate progress reports,

- a written formal report on project activities, and

- an oral presentation to a technical or industry advisor.

While the Senior Project is a two-quarter course in most of Cal Poly's programs, it is now being offered as a one-quarter course in the IT program. A short 11-week time frame often presents a barrier in completing a project and meeting the objectives. Moreover, many students spent a week or so planning their projects. As a result a significant portion of the time available is lost, which often leads to student frustration and pre-mature project submission. Thus it was necessary to devise and implement a new approach to manage this course in a more efficient manner to:

- eliminate or minimize the non-value added time,

- maximize available project time for students,

- reduce/eliminate the volume of papers exchanged among students, faculty advisors (FA) and technical advisors (TA), and

- reduce delays in communications caused by handling paper-based progress reports and other documents.

Based on these considerations, we present a paperless communication approach for managing a senior project course as a means to decrease the amount of non-value added time expended by students and teachers. A common lean principle known as "value stream mapping" (VSM) is deployed to document the flow of information and paper in the previous state of the Senior Project course. VSM is also used to reveal the amount of value-added and non-value added time expended and the opportunities for improving the efficiency of course management.

\section{STATUS OF PAPER-BASED SYSTEM}

Prior to Fall 2005 a paper-based system was used to manage IT461. During the first week of an academic quarter the students were introduced to the course and were asked to select a topic for their project. The following is a list that represents the milestones that students were expected to achieve during the course. They:

October 28 - 31, 2006, San Diego, CA 
- wrote a proposal for review and approval by the FA,

- wrote an Agreement/Contract,

- attended class meeting/orientation,

- submitted a progress report (PR\#1) to FA (literature review, solution concept),

- reviewed written comments and corrections by FA of PR\#1,

- submitted PR\#2 to FA (detailed solution, testing/evaluation),

- reviewed written comments and corrections by FA of PR\#2,

- $\quad$ submitted a final report to FA and TA, and

- prepared a final presentation.

In addition to the above paper-based activities, students met their technical advisors, collected data, worked on problem analysis, and designed and developed feasible solutions. A technical advisor could be a professional from industry or one of the Cal Poly faculty members with expertise in the project area.

\section{Value added/non-value added times}

In a senior project course such as IT461, regular interactions between faculty advisor and students are essential for the success of the projects. Moreover, there is a significant interdependency between the work done by both the student and the FA. For example, often a timely review of a project progress report by the FA depends upon prompt submission of the report by students. Conversely, the amount of time available for project work by students is dependent on how soon they get feedback from the FA. In such an environment, value-added (VA) and non-value added (NVA) times are highly sensitive to delays by either side. Logically, in a short 11-week time span any decrease in NVA contributes to more time for students to work on their projects, and provides faculty some extra time that can be spent on other activities.

In recent years a new process analysis tool known as value stream mapping (VSM) has been used by industry and academia to document the VA and NVA activities and associated times. The driving force behind using VSM is the concept of lean thinking, which has drawn the attention of many organizations, particularly, manufacturing companies. VSM is the foundational tool used to put companies on the cutting edge of transformation from traditional to lean manufacturing [1]. VSM is used to analyze the current state of the manufacturing process and identify opportunities for improvement or "kaizen" (a focused, quick improvement event). A future or "ideal" state map is developed by incorporating the kaizen ideas. The result is a vision or roadmap for developing and implementing lean manufacturing systems [2].

A generally accepted definition of "lean" in the industrial community is that it is a systematic approach to identifying and eliminating waste (non-value added activities) through continuous improvement by flowing the product at the pull of the customer in pursuit of perfection [3].

VSM, as envisioned above, serves as a methodology for management, engineers, suppliers, and customers to recognize and develop an achievable plan to eliminate waste. Waste, in lean terms, refers to activities that do not add value for the final customer. Non-added value includes the creation of inventory, defective products, overproduction of goods not currently needed, equipment setup, movement of people or transport of goods, employee wait-time, and wasted employee knowledge [4].

Since VSM is a general purpose process analysis tool its application can go beyond the industrial domain. However, to apply VSM in any domain one should define the meaning of waste and non-value added activities applicable to that domain. In our case the domain is academic, more specifically it is a capstone senior project course. Table I shows typical waste and NVA activities in the industrial domain and their equivalent terms in a senior project course.

We developed a VSM for IT461 to depict the flow of paper and information for course management from project selection to final project delivery. Figure 1 shows the VSM for the state of IT461 prior to Fall 2005. The VSM depicts a number of non-value added activities. As Table 1 indicates non-value added times in a senior project course can be attributed to a number of activities such as student waiting time for getting feedback from the FA or reworking incorrect project reports.

TABLE I

INTERPRETATION OF WASTE IN INDUSTRY AND ACADEMIA

\begin{tabular}{|l|l|}
\hline \multicolumn{1}{|c|}{ In Industry } & In Academia (Senior Project) \\
\hline $\begin{array}{l}\text { Inventory of materials } \\
\text { (batch processing) }\end{array}$ & $\begin{array}{l}\text { Stack of progress reports and forms } \\
\text { (slow data retrieval) }\end{array}$ \\
\hline Defective parts & $\begin{array}{l}\text { Incomplete/incorrect reports } \\
\text { (rework, slow feedback) }\end{array}$ \\
\hline $\begin{array}{l}\text { Movement of people } \\
\text { Transport of goods }\end{array}$ & $\begin{array}{l}\text { Physical delivery of progress } \\
\text { reports, final project, forms }\end{array}$ \\
\hline $\begin{array}{l}\text { Employees wait-time } \\
\text { faculty }\end{array}$ \\
\hline $\begin{array}{l}\text { Equipment non-production time } \\
\text { (machine setup) }\end{array}$ & $\begin{array}{l}\text { Correcting reports, writing } \\
\text { comments on papers }\end{array}$ \\
\hline
\end{tabular}

Further examination of VSM (Figure 1) reveals some important numerical data. These data are summarized in Table II. Perhaps the most significant data is the ratio of NVA to total time available for each project, which in IT461 case is equal to $35 \%$. This ratio is a good indicator of the 


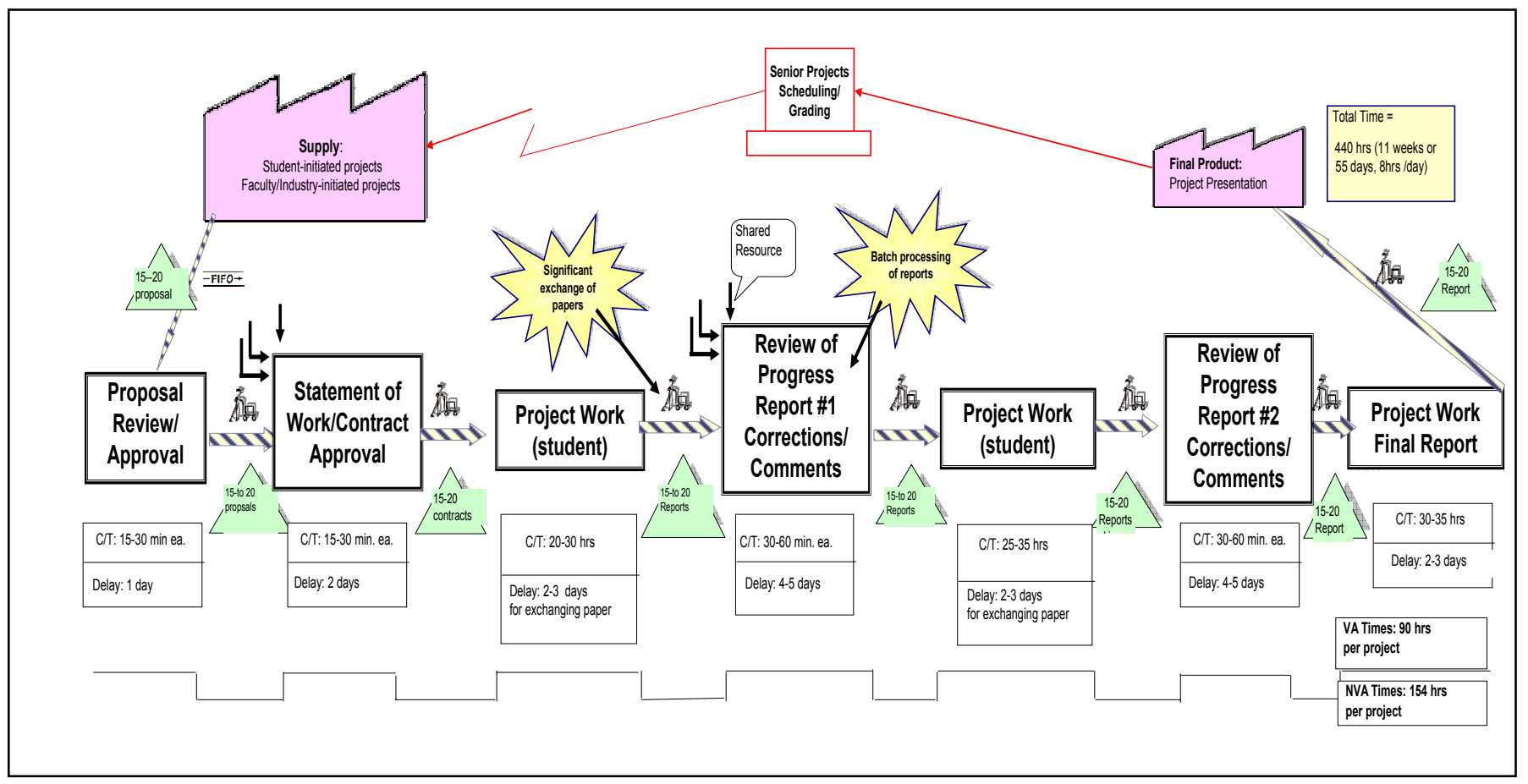

FIGURE 1 VALUE STREAM MAP FOR SENIOR PROJECT IT461 COURSE

percentage of available time that has been wasted. Any improvement in managing the course should be measured as a lower ratio of NVA to total time, which translates into a larger amount of time available for students to spend on valueadded project activities.

TABLE II

NUMERICAL DATA FROM VSM

\begin{tabular}{|l|l|}
\hline Total Time & $\begin{array}{l}440 \mathrm{hrs}(11 \text { weeks or } \\
55 \text { days, } 8 \text { hrs/day) }\end{array}$ \\
\hline Value-Added (VA) Time & $90 \mathrm{hrs}$ \\
\hline Non-Value Added (NVA) Time & $154 \mathrm{hrs}$ \\
\hline Ratio of NVA to Total Time & $35 \%$ \\
\hline
\end{tabular}

\section{PAPERLESS COURSE MANAGEMENT}

In this era of digital technology and network communications, a paper-based data flow can create a bottleneck or at minimum can slow down any process that depends on an information system. The impact of such slowness can be significant in an academic environment particularly in a senior project course where typically a limited amount of time is available for completing a project. Moreover, paper-based data communication could take too much space, not to mention the cost of the paper.

Paperless processes have emerged in all types of industries and businesses. Generally, the elimination of paper is not the main objective. Instead, the goal is to increase customer benefits, and in our case, benefits to the students and faculty, resulting in higher productivity.
In recent decades, a host of technologies, introduced have led to the development of an infrastructure for paperless processes. With the advent of the internet, paper-based processes have become less productive. People are now accustomed to information at their fingertips. In addition to popular email communication, the academic community in the U.S. has adopted a password-controlled WEB portal such as Blackboard or WEB CT.

Table II shows that there was a significant amount of NVA in IT461. Clearly, there was a need for change to decrease NVA and provide more VA time for students and faculty. We decided to take advantage of an available WEB portal technology and email system to establish a paperless communication system. At the beginning of the Fall 2005 quarter, students were introduced to this course management approach, which offered the following features:

- electronic announcements to all students 2-3 times prior to the first day of classes,

- $\quad$ proposal and contract/agreement submission and approval via email,

- $\quad$ posting progress reports via WEB portal,

- $\quad$ providing feedback to students via email,

- frequent communication between FA and TA via email/WEB portal, and

- $\quad$ posting guidelines on WEB portal.

A major component of the new course management system was the development of a set of electronic guidelines for students, faculty and industry advisors. These guidelines 
replaced a printed course manual, which was merely a writing style guide without any instruction on how to handle the various industrial-based projects. The new guidelines can be quickly updated every quarter by a FA and includes the following items:

- IT 461 Senior Project General Guidelines,

- requirements for the project proposal,

- an example of the agreement/contract,

- requirements for the progress report, and

- requirements for the final report:

- general outline, and

- form and style.

\section{Batch processing vs. one-piece flow}

One of the well known sources of waste in industry is batch and-queue processing of materials. This approach often causes the accumulation of materials throughout a facility. In a lean thinking approach, batch-and-queue processing is replaced by one-piece flow. This approach minimizes or eliminates workin-process (WIP) inventory, which is a major source of NVA times.

In an academic setting, where papers are a common medium for exchanging information between students and faculty, papers create similar WIP inventories. As Figure 1 indicates, a batch of 15 to 20 progress reports may wait in a faculty member's office for days before undergoing the review, comment, and correction process. The majority of the reports were delivered to the FA on the due date, were processed, and held until they were picked up by students. This batch-and-queue processing of reports resulted in long delays in returning reports to students as depicted in the VSM (Figure 1).

We observed a drastic reduction in WIP reports after deploying the paperless course management. This new setting provided an instant exchange of reports between FA and students and one-piece (one-report) processing. More specifically, the FA retrieves a progress report from WEB portal and after reviewing, he/she places side textboxes as a means to express his/her views about the project. Finally, the reviewed file is emailed to the student. Progress report throughput time was significantly reduced as a result of following savings:

- faculty time spent reviewing files dropped by $30 \%$ due to faster copy and paste functions,

- project reports and documents were delivered electronically, reducing waiting time from days to hours, and

- WIP was reduced by $75 \%$.

As shown in Table III, the new ratio of NVA to total time was less than $6 \%$, as compared to $35 \%$ in paper-based system. The new NVA was 26 hours as compared to the previous value of 154 hours, which translates into an additional 138 hours available for project work. Clearly, there is a significant improvement in efficiency as a result of adopting a paperless course management approach.

TABLE III

PERFORMANCE DATA FROM VSM AFTER ADOPTING PAPERLESS COURSE MANAGEMENT

\begin{tabular}{|l|c|}
\hline Total Time & $\begin{array}{c}440 \text { hrs (11 weeks or } \\
55 \text { days, } 8 \text { hrs /day) }\end{array}$ \\
\hline Value-Added Time & $>90$ Hrs \\
\hline Non-Value Added (NVA) Time & $<26$ Hrs \\
\hline Ratio of NVA to Total Time & $<6 \%$ \\
\hline
\end{tabular}

\section{COURSE EVALUATION}

Typically, no course evaluation was conducted in previous offerings of IT461 due to the non-lecture nature of the course. However, we felt that a formal evaluation was needed in the light of the implementation of the new course management approach. As a result, a survey questionnaire was developed, which focused on the paperless management aspects of the course. Similar methods of evaluation have also been applied elsewhere [5],[6],[7]. The rubric for evaluation of IT461 is described in Table IV.

TABLE IV

\section{RUBRIC FOR IT461 EVALUATION}

\begin{tabular}{|l|l|}
\hline Questions & \# Inputs \\
\hline $\begin{array}{l}\text { 1) Paperless communication saved my time significantly by } \\
\text { expediting the flow of information and documents. }\end{array}$ & 20 \\
\hline $\begin{array}{l}\text { 2) Interaction with the faculty advisor through email and } \\
\text { Blackboard aided timely progression of my project. }\end{array}$ & 19 \\
\hline $\begin{array}{l}\text { 3) Posting the guidelines on Blackboard was advantageous over a } \\
\text { traditional printed manual that used to be obtained from the } \\
\text { bookstore. }\end{array}$ & 19 \\
\hline $\begin{array}{l}\text { 4) The guidelines posted on Blackboard provided me with a clear } \\
\text { understanding of expectations of Senior Project course. }\end{array}$ & 19 \\
\hline $\begin{array}{l}\text { 5) The guidelines posted on Blackboard have helped me to } \\
\text { manage my project in a timely fashion. }\end{array}$ & 17 \\
\hline $\begin{array}{l}\text { 6) The FORMAT-STYLE guideline was clear and helped me to } \\
\text { format and style the final report. }\end{array}$ & 19 \\
\hline $\begin{array}{l}\text { 7) The use of the Gantt chart throughout the project development } \\
\text { was helpful in managing my project. }\end{array}$ & 15 \\
\hline $\begin{array}{l}\text { 8) Electronic interaction with faculty and industry advisors was } \\
\text { helpful in streamlining my industry-based project. }\end{array}$ & 12 \\
\hline $\begin{array}{l}\text { 9) The periodic emails sent by the faculty advisor were helpful in } \\
\text { planning for the course and finding a topic on time. }\end{array}$ & 16 \\
\hline
\end{tabular}

The results of an on-line survey by 20 students who were enrolled in the Fall 2005 quarter are shown in Table V. To illustrate the level of the students' satisfaction, the results of the survey were plotted in a bar chart and are shown in Figure 2.

There are a number of significant outcomes that arise from the paperless management that we applied to IT461. The first and most important is the increase in time available for students to work on their project. Over $80 \%$ of respondents agreed or strongly agreed that using such paperless course management saved a significant amount of time, which would

\section{TABle V}

October 28 - 31, 2006, San Diego, CA

\section{1-4244-0257-3/06/\$20.00 @ 2006 IEEE}

\section{$36^{\text {th }}$ ASEE/IEEE Frontiers in Education Conference}


RESULTS OF EVALUATION

\begin{tabular}{|c|c|c|c|c|}
\hline \multirow{4}{*}{ Question } & \multicolumn{4}{|c|}{ \% of Respondents } \\
\hline & \multirow{2}{*}{\multicolumn{2}{|c|}{$\begin{array}{l}\text { 1. Strongly Disagree } \\
\text { 3. Agree }\end{array}$}} & \multirow{2}{*}{\multicolumn{2}{|c|}{$\begin{array}{l}\text { 2. Disagree } \\
\text { 4. Strongly Agree }\end{array}$}} \\
\hline & & & & \\
\hline & 1 & 2 & 3 & 4 \\
\hline 1 & 0 & 0 & 20 & 80 \\
\hline 2 & 0 & 10 & 40 & 50 \\
\hline 3 & 0 & 5 & 35 & 60 \\
\hline 4 & 0 & 5 & 35 & 60 \\
\hline 5 & 0 & 10 & 40 & 50 \\
\hline 6 & 0 & 10 & 50 & 40 \\
\hline 7 & 0 & 20 & 50 & 30 \\
\hline 8 & 5 & 10 & 35 & 50 \\
\hline 9 & 0 & 0 & 40 & 60 \\
\hline
\end{tabular}

otherwise have been spent on delivery of paper-based forms and progress reports to the FA, and waiting for his/her written feedback. Eighty-five percent of respondents felt that the ability to access course guidelines online was effective in streamlining the project tasks and documentation.

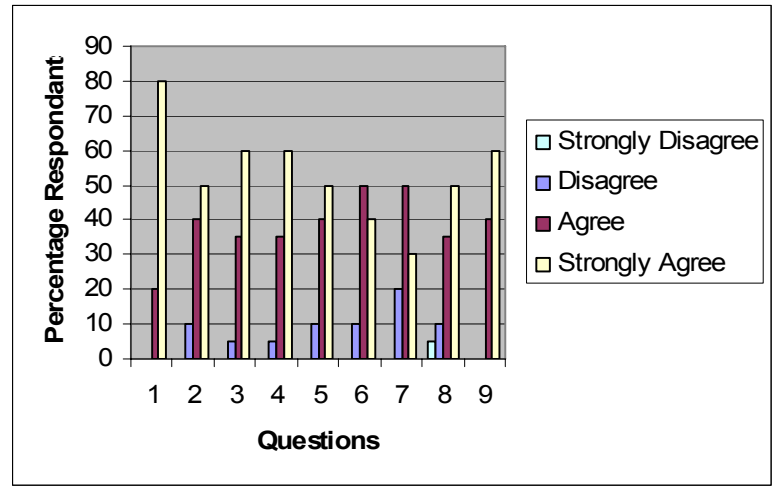

FIGURE 2

EVALUATION RESULTS

\section{EXAMPLES OF PROJECTS}

Although industrial technology students may choose a topic for their projects from a variety of sources we encourage them to work on industry/business-based (IB) projects. We believe such projects are an excellent way to familiarize students with the industrial environment and the types of problems they may face after graduation. However, taking IB projects often involves an extra workload for students including trips to offcampus sites and higher expectations of IB advisors. Implemented during an 11-week quarter system, we find that the paperless course management approach provides students with valuable time, which they can use to complete highquality senior projects. In the Fall of 2005, 12 out of 20 projects were conducted with regional industry and businesses. The following is a description of four of the projects that were developed over the period of restructuring IT461. The estimated non-value added time and the ratio of NVA to total available time are shown for each project.

New United Motor Manufacturing Inc. (NUMMI)
Project Title: Kaizan and Value Engineering Analysis Implementation of Production Control

The manpower associated with creating reports in the New United Motors Manufacturing Inc. Control Room makes managing production issues and breakdowns throughout the plant difficult.

This senior project presented an automatic report generating tool to reduce the amount of time that it takes to generate the major reports for the control room. The three main reports generated were a daily delinquent vehicle report (manages throughput in the plant), a daily report (shows all major production information from the previous day) and a weekly report (shows all major production issues for the week). The reports also include an electronic information board that displays the current production issues inside the control room.

Excel was the main program used to develop these reports. A master database was created that held all information plant wide and had an automated data input system. The daily and weekly reports were created by importing information from this database. The introduction of automated report generators decreased the amount of time to prepare major reports by up to $50 \%$.

$\mathrm{NVA}=18 \mathrm{hrs}$

NVA/total time $=4 \%$

\section{Next Intent Inc.}

Project Title: Implementation of Lean Manufacturing Techniques Involving High Variety, Low Volume Manufacturing

This project presented research involving implementation of lean manufacturing techniques for a high variety, low volume (HVLV) manufacturer. Prior to this study, there have been many instances of lean thinking taking place all over the globe, primarily in low variety, high volume, repeat applications. The intention of this project was to find a correlation between these two applications and implement improvements where applicable. The desired end result was to increase productivity.

This project focused on eliminating muda or the waste in a relatively small company of only 29 employees, located in San Luis Obispo, CA. The focus was on relatively easy to implement improvements on "low hanging fruits". Next Intent is configured to handle both prototype work and production machining in small to medium lot sizes, placing them in the category of HVLV.

The results of this study illustrated a number of possible solutions all geared toward increasing productivity. After compiling data from surveys, scorecards, and personal interviews with machinists, a solution was proposed that focused on eliminating the "external setup" in the paperwork supplied by the quality assurance department. While the project revealed opportunities for improvement, further 
studies are needed to develop detailed designs and plans for implementing external machine setups.

$\mathrm{NVA}=21 \mathrm{hrs}$

$\mathrm{NVA} /$ total time $=4.7 \%$

\section{Zurn Wilkins Inc.}

Project Title: Value Stream Mapping of Small Backflow Preventer Production

The accumulation of excess inventory of both finished goods and work-in-process goods is a problem that plagues many manufacturing companies. This accumulation of excess inventory is problematic in that it hides quality issues, increases holding costs, and prevents proper control of a production environment. The purpose of this study was to use one of the standard tools of lean manufacturing to investigate a production line for opportunities for implementation of lean manufacturing principles. The tool used was the practice of value-stream mapping. Value-stream mapping was used to examine the small backflow preventer production line at the Zurn/Wilkins facility in Paso Robles, CA. This study was also intended to generate interest for discussion of lean manufacturing principles in other areas of Zurn/Wilkins production system.

By focusing on the practice of value-stream mapping and the implementation of a supermarket system, kanban, and the concept of kaizen improvements, this study provided Zurn/Wilkins with an example of the potential future state of their production line. There were multiple kaizen improvement opportunities identified by this study. Each workstation needing these improvements could prove to be a separate project.

$\mathrm{NVA}=15 \mathrm{hrs}$

Ratio NVA/total time $=3.4 \%$

\section{The Boeing-Rocketdyne Company}

Project Title: Integrated Visual Signs and Controls

This project was intended to improve the manufacturing control system of Rocketdyne's Space division by investigating the possible solutions to critical path movement of materials. A wireless communication system was selected to help eliminate waste in terms of operators standing around, inventory control, waste in production time and machine down time. The detailed specifications of an andon light communication system were provided to control and monitor the flow of raw and finished materials traveling throughout the facility in a more organized fashion. The proposed system will also help to control the amount of on-hand inventory within the facility.

$\mathrm{NVA}=26 \mathrm{hrs}$

$\mathrm{NVA} /$ total time $=5.9 \%$

\section{CONCLUSION}

Our short timeframe, an 11-week academic quarter, requires that we manage our senior project capstone course with a high degree of efficiency. As described herein, the paperless communication approach that we developed for the Fall 2005 course, reduced the amount of non-value added, nonproductive time expended by both students and faculty. This allowed more time for students to focus on their projects and allowed project administrators to better manage the time they spent on the evaluating student's efforts.

This study was intended to stimulate the thinking of other faculty in engineering and technology programs, to consider improving the efficiency of capstone senior project course management using a paperless communication approach. While there was originally little interaction between students and faculty, this approach enables significant day-to-day communication and supervision of the progress of the project.

We hope that this paper describing our experience with paperless course management will be useful for other educators, even if their courses do not have similar time constraints. However, a tangible benefit may be achieved when time is at a premium for both students and faculty.

\section{REFERENCES}

[1] Harris, G. and Donatelli, A. (2005). "Value Stream Mapping as a Lean Management Tool", Retrieved December 20, 2005, from www.atnlean.com/valuestream-tool.pdf.

[2] Rother, M., and Shook, J.(1999)."Learning to See", The Lean Enterprise Institution, Brookline, MA.

[3] Verma, A., Hughes, J.and Christman, S., " Enhancing Instruction in Lean Manufacturing Through Development of Simulation Activities in Shipbuilding Operation", Procs. of the 2004 ASEE Annual Conf. July 2004, Salt Lake City UT, Session 2663.

[4] Ono, T., "Toyota Production System: Beyond Large-Scale Production", Cambridge, Mass, Productivity Press, 1988.

[5] Doty, R. T. "A Practice-based Senior Design Experience", Proceedings of the 2002 ASEE Annual Conference and Exposition, Montreal, Quebec, June 16 - 19, 2002. Paper \# 204.

[6] Rossetti, M.D., Cassady, C.R and Schneider, K. "Assessing an Industry based IE Senior Design Course", Proceedings of the 2002 ASEE Annual Conference and Exposition, Montreal, Quebec, June 2002.

[7] Sorensen, C.D., Magleby, S.P. and Todd, R.H., "Designing a senior capstone course to satisfy industrial customers", Journal of Engineering Education, v. 82, no. 2, 1993, pp. 92-100. 